\title{
ФЕНОМЕН «ПУРИНТОКСИЧНОСТИ» ПРИ САХАРНОМ ДИАБЕТЕ 2 ТИПА
}

\author{
Мадянов И.В.
}

ГАУ ДПО «Институт усовершенствования врачей» МЗ Чувашии, Чебоксары

ЦЕЛЬ: обосновать наличие при сахарном диабете (СД) 2 типа (СД-2) феномена «пуринтоксичности».

МЕтоДЫ: в работе отражены результаты многолетних исследований автора, в ходе которых обследовано 2,5 тыс. здоровых и больных СД чел; в экспериментах задействовано более 300 лабораторных животных. Определение мочевой кислоты (МК) и других показателей пуринового обмена осуществлялось методами прямой спектрофотометрии с использованием в качестве контроля соответствующих тест-систем.

PЕЗУЛЬтАТЫ: на моделях экспериментального предиабета, латентного и явного СД у белых беспородных крыс установлено, что диабетогенность гиперурикемии (ГУ), вызванной экзогенным введением МК, тем выраженнее, чем значительнее исходные нарушения углеводного обмена. Установлено, что как самостоятельный этиологический фактор развития СД по своей активности МК значительно (в десятки, сотни раз) уступает аллоксану; вместе с тем ГУ существенно потенцирует диабетогенные эффекты малых (субдиабетогенных) доз аллоксана. Развитие аллоксанового СД сопровождается усилением активности ксантиноксидазы (КО) в инсулярном аппарате поджелудочной железы. Предварительная (до инъекции аллоксана) ингибиция этого фермента аллопуринолом способна улучшить состояние аллоксандиабетных крыс.

При эпидемиологических исследованиях свободной выборки популяции установлена четкая связь ГУ с метаболическим синдромом и его компонентами. Наличие ГУ увеличивает риск нарушенной толерантности к глюкозе и СД-2 в 4 раза.

Манифестный СД-2 характеризуется нарастанием в крови концентраций пуриновых оснований, активацией KO, угнетением реутилизации пуринов и, как следствие, чрезвычайно усиленной продукцией МК, которая свойственна значительной части (76,7\%) больных СД-2. Гипергликемия и глюкозурия усиливают выведение МК через почки, поэтому развитие ГУ при СД-2 очень тесно связано с нефропатией. Снижение ренальной экскреции уратов при ГУ при фиксируется у 68,9\% больных СД-2, причем у более чем половины $(59,1 \%)$ из них она связана с нарушением канальцевой секрецией МК. При перепроизводстве МК у больных СД-2 формируется условия для развития нефропатии по типу «подагрической» почки. По совокупности влияния пуринового дисметаболизма при СД-2 на инсулярный аппарат, органы и системы наблюдается аналогия с феноменами глюко- и липотоксичности, свойственные СД. Установлено, что ингибиторы КО (аллопуринол, фебуксостат) в условиях перепроизводства МК способны оказывать при СД-2 многоплановое позитивное действие на метаболизм в целом.

ВЫводЫ: наряду с феноменами «глюкотоксичности» и «липотоксичности» в процессе развития и прогрессирования СД-2 патогенетическое значение приобретает феномен «пуринтоксичности». ГУ, активация ключевого фермента окисления пуринов КО способны оказывать $\beta$-цитотоксичекое действие на инсулярный аппарат, а также потенцировать формирование органных поражений, в том числе нефропатии по типу «подагрической» почки. Патогенетически оправданным при феномене «пуринотоксичности» у больных СД-2 является использование в комплексном лечении ингибиторов КО - аллопуринола или фебуксостата.

КЛЮЧЕВЫЕ СЛОВА: сахарный диабет 2 типа; мочевая кислота; гиперурикемия; ксантиноксидаза; патология почек; аллопуринол; фебуксостат. 